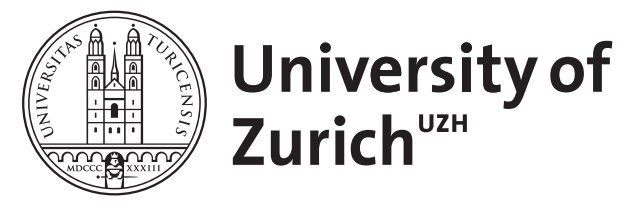

\title{
The first scallop
}

\author{
Hautmann, M
}

\begin{abstract}
Scallops (Pectinidae) are a highly diverse bivalve family with a long evolutionary history, but insufficient knowledge on the internal shell characters of initial taxa has hampered clarification of their phylogenetic roots. Here, morphological details of the shell interior of the basal pectinid Pleuronectites laevigatus from the Middle Triassic are documented for the first time. It is shown that ligament morphology, lack of internal buttresses and hinge articulation, presence of a right anterior auricular scroll, procrescent discs, and differential valve convexity of Pleuronectites link Pectinidae with Early Triassic aviculopectinoids rather than with entoliids, as recently proposed. The key adaptations of Pectinidae, i.e. the ctenolium and the alivincular-alate ligament system, probably evolved in conjunction with a marked size increase that required improvements in the shell attachment and in the system for opening the valves. Although Pleuronectites laevigatus is recognized as the earliest known member of the Pectinidae, a diphyletic origin of this family from different stocks within the Aviculopectinoidea cannot be ruled out.
\end{abstract}

DOI: https://doi.org/10.1007/s12542-009-0041-5

Posted at the Zurich Open Repository and Archive, University of Zurich ZORA URL: https://doi.org/10.5167/uzh-21138

Journal Article

Published Version

Originally published at:

Hautmann, M (2010). The first scallop. Paläontologische Zeitschrift, 84:317-322.

DOI: https://doi.org/10.1007/s12542-009-0041-5 


\title{
The first scallop
}

\author{
Michael Hautmann
}

Received: 22 July 2009/Accepted: 11 September 2009/Published online: 29 September 2009

(C) Springer-Verlag 2009

\begin{abstract}
Scallops (Pectinidae) are a highly diverse bivalve family with a long evolutionary history, but insufficient knowledge on the internal shell characters of initial taxa has hampered clarification of their phylogenetic roots. Here, morphological details of the shell interior of the basal pectinid Pleuronectites laevigatus from the Middle Triassic are documented for the first time. It is shown that ligament morphology, lack of internal buttresses and hinge articulation, presence of a right anterior auricular scroll, procrescent discs, and differential valve convexity of Pleuronectites link Pectinidae with Early Triassic aviculopectinoids rather than with entoliids, as recently proposed. The key adaptations of Pectinidae, i.e. the ctenolium and the alivincular-alate ligament system, probably evolved in conjunction with a marked size increase that required improvements in the shell attachment and in the system for opening the valves. Although Pleuronectites laevigatus is recognized as the earliest known member of the Pectinidae, a diphyletic origin of this family from different stocks within the Aviculopectinoidea cannot be ruled out.
\end{abstract}

Keywords Bivalves · Pectinidae - Triassic Evolution · Life habit

Kurzfassung Kammmuscheln (Pectinidae) sind eine hoch diverse Muschelfamilie mit einer langen Stammesgeschichte, aber mangelnde Kenntnis der inneren Schalenmerkmale bei frühen Vertretern dieser Gruppe haben die Klärung ihrer Abstammung erschwert. In diesem Artikel werden erstmalig Details der inneren Morphologie

M. Hautmann ( $\square)$

Paläontologisches Institut und Museum, Universität Zurich,

Karl Schmid-Strasse 4, 8006 Zurich, Switzerland

e-mail: michael.hautmann@pim.uzh.ch des basalen Pectiniden Pleuronectites laevigatus beschrieben. Es zeigt sich, dass Pleuronectites auf Grund (1) der Morphologie des Ligamentes, (2) des Fehlens von Schlosszähnen und internen Leisten, (3) des Vorhandenseins eines Umschlages am rechten Vorderohr, (4) procrescenter Klappen und (5) der unterschiedlichen Wölbung der beiden Klappen bestimmten Vertretern der Aviculopectinoidea nahe steht. Eine Herkunft der Pectinidae aus dieser Überfamilie ist daher wahrscheinlicher als die kürzlich vorgeschlagene Abstammung von Entoliidae. Die Schlüsselmerkmale der Pectinidae, nämlich das alivincular-alate Ligament und die Anwesenheit eines Ctenoliums, haben sich wahrscheinlich im Zusammenhang mit einer deutlichen Größenzunahme entwickelt, die Verbesserungen im Bereich der Befestigung des Tieres und dem System zum Öffnen der Klappen erforderlich gemacht haben. Obwohl Pleuronectites laevigatus als ältester bekannter Vertreter der Pectinidae anzusehen ist, kann auch eine diphyletische Herkunft dieser Familie aus unterschiedlichen Wurzeln innerhalb der Aviculopectinoidea nicht ausgeschlossen werden.

Schlüsselwörter Muscheln · Pectinidae $\cdot$ Trias · Evolution · Lebensweise

\section{Introduction}

Hardly any bivalve family rivals the immense number of species that Pectinidae Rafinesque-Schmaltz, 1815 (scallops) evolved during nearly 250 million years of phylogeny. Apart from sheer diversity, also commercial importance and the aesthetics of the shell have attracted considerable interest in this family. Yet, the phylogenetic origin of the Pectinidae has been controversial. 
The current consensus is that two key characters define the Pectinidae (Waller 2006). The first is the alivincularalate ligament condition (Hautmann 2004), which is characterized by the internal position of the resilium with respect to the lateral parts of the ligament and by a resilium with an uncalcified median core. The internal position of the resilium results from the ventrally directed growth of this structure, whereas the lateral parts of the ligament remain more or less at the dorsal margin, with no ventral shift as shell growth proceeds. This is an easily recognizable difference to the primitive alivincular-areate ligament type, in which the lateral ligament and submarginal resilium shift jointly in a ventral direction during ontogeny (Hautmann 2004). The second key character of pectinids is a comb-like row of denticles along the ventral edge of the byssal notch termed ctenolium. The ctenolium strengthens byssal attachment by spreading byssal threads where they pass over the disk (Waller 1984).

Pectinidae share the alivincular-alate ligament system with the geologically older Entoliidae Korobkov, 1960 (herein understood to include "Pernopectinidae" and "Entolioididae"), whereas a ctenolium is unique to Pectinidae. Waller (2006) suggested that the similarity in the ligament system sufficiently establishes monophyly of Entoliidae and the pectinid clade. By contrast, the traditional view first expressed by Newell (1938) is that Entoliidae were too specialized to give rise to Pectinidae, implying that the shared presence of an alivincular-alate ligament system evolved convergently.

The major problem in unravelling the origin of pectinids is the lack of sufficient morphological data on early representatives of this family. It is generally agreed that the oldest taxon with a ctenolium and thus the earliest known pectinid is Pleuronectites laevigatus Schlotheim, 1820 from the Anisian-Ladinian (Middle Triassic) of the Germanic basin (Waller 1984; Newell and Boyd 1995). Waller (2006, p. 331) mentioned that "Praechlamys" reticulata (Schlotheim, 1823), which first appeared in the Lower Wellenkalk (Bithynian stage of the Anisian) and thus only slightly later than $P$. laevigatus (first appearing in the Upper Buntsandstein [Aegean stage]; Schmidt 1938, p. 95; for chronostratigraphy see Deutsche Stratigraphische Kommission 2002), also had a ctenolium. However, this observation has not been illustrated, and the ligament system of "Praechlamys" reticulata is unknown.

\section{New data on the oldest pectinid}

Pleuronectites laevigatus was a common component of benthic faunas in Middle Triassic epicontinental seas and has repeatedly been described and figured (e.g., Newell 1969; Hagdorn 1995; Waller 2005). Yet, P. laevigatus is typically preserved with conjoined valves hiding all internal shell characters. Moreover, the originally aragonitic inner shell layer has generally been dissolved during diagenesis (Waller 2005, p. 39), and consequently, all structures formed by this part of the shell have been destroyed. A unique exception from the described state of preservation is a silicified right valve from the Upper Muschelkalk (Early Ladinian) of Nagold, southwest Germany, which is housed in the collection of the Staatliches Museum für Naturkunde Stuttgart (SMNS, coll. no. 18926), Germany. A sketchy drawing of this specimen was given by Schmidt (1928, Fig. 338 b-c), but it has never been described or adequately illustrated. Re-examination of this specimen revealed new character details that have important bearings on the taxonomy and early phylogeny of scallops.

The silicified Stuttgart specimen was extracted from the rock by etching (Schmidt 1928, p. 158). The shell is fairly complete apart from the posteroventral part of the disc, where a fragment has broken off. A cross section exposed by the fracture shows that silicification proceeded from the outer and inner shell surfaces, leaving the middle part of the shell less silicified and highly porous after etching. No primary shell structures could be detected under the stereomicroscope.

The present specimen is about $6.8 \mathrm{~cm}$ high and $7 \mathrm{~cm}$ long, which translates to an original shell size of ca. $8 \mathrm{~cm}$ height and $7.4 \mathrm{~cm}$ length. The disc is nearly flat, procrescent, and externally smooth except for growth lines (Fig. 1a). The small, pointed beak is anteriorly directed and divides the hinge line in two parts of about equal length. The posterior auricle is obtuse but well demarcated from the disk. The anterior auricle projects distally above the hinge line; ventrally, it encloses a deep byssal notch (Fig. 1a-c).

The ctenolium is only partly preserved in the present specimen (Fig. 1c), showing relics of at least four denticles. For an illustration of the complete ctenolium of Pleuronectites laevigatus see, e.g., Newell (1969, Fig. C63).

The inner side of the disk is smooth (Fig. 1b), with no basal auricular and lateral disk buttresses (terms after Waller 2006, p. 315, Fig. 2). Contrary to Waller (2005, p. 39), the hinge of Pleuronectites laevigatus lacks resilialand infraresilial teeth (Fig. 1d). It also lacks an outer ligament articulation (Fig. 1d). However, articulation of the valves was supported by an anterior auricular scroll in the right valve (Fig. 1c).

The ligament system of the Stuttgart specimen has narrow bourrelets on either side of the resilifer, indicating that the growth direction of the lateral ligament had a small ventral component (Fig. 1d). However, the resilifer clearly occupies an internal position, which is characteristic for the alivincular-alate ligament system (Hautmann 2004). 
Fig. 1 Pleuronectites

laevigatus, silicified right valve from the upper Muschelkalk of Nagold, Germany (SMNS 18926). a shell exterior; b shell interior; $\mathbf{c}$ details of right anterior auricle, showing auricular scroll (as) and byssal notch with abraded ctenolium (c); d details of ligament area with small bourrelets $(b)$ and remnants of fibrous ligament $(f t)$ in the internal resilifer. Scale bars represent $1 \mathrm{~cm}$
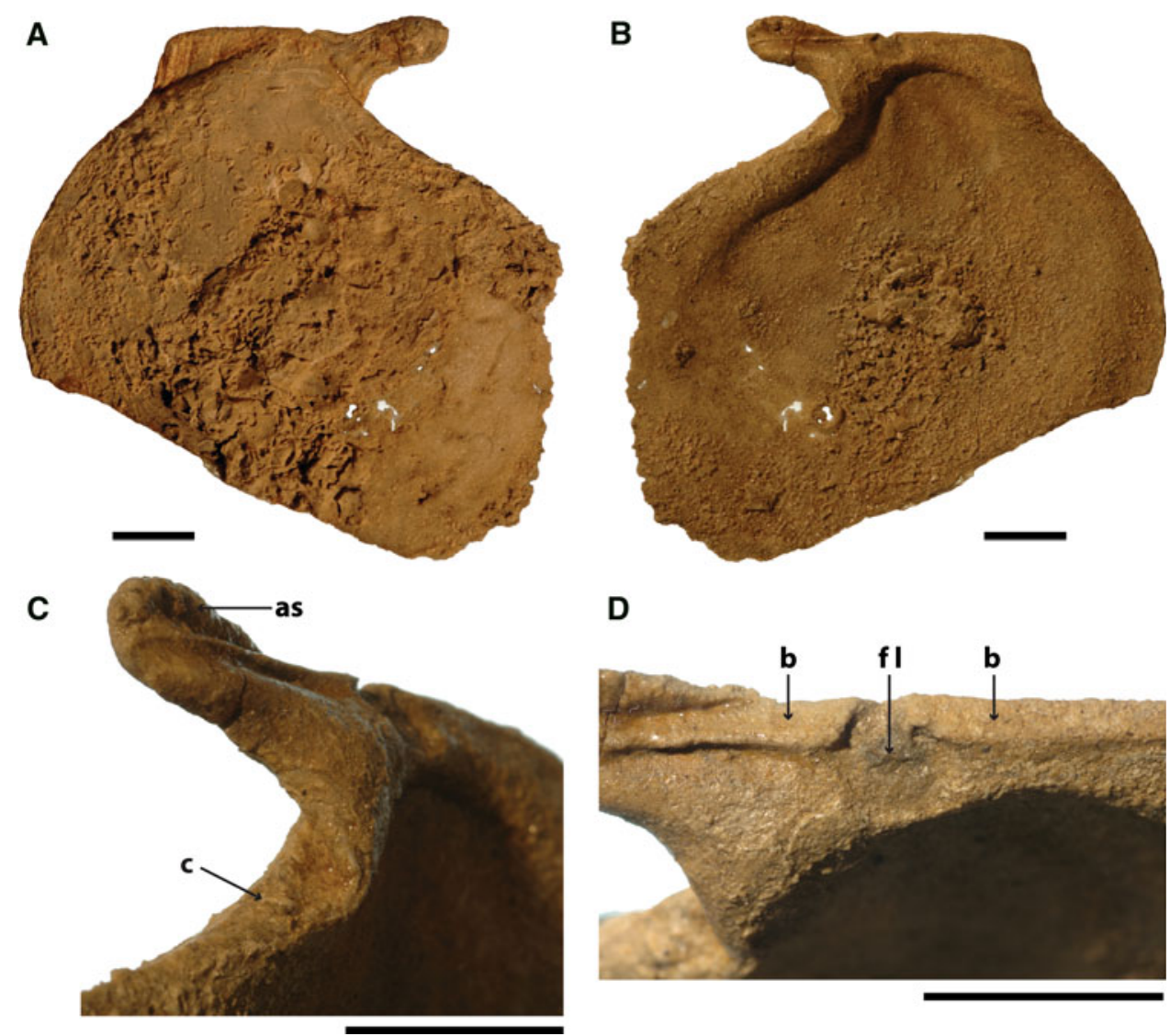

D

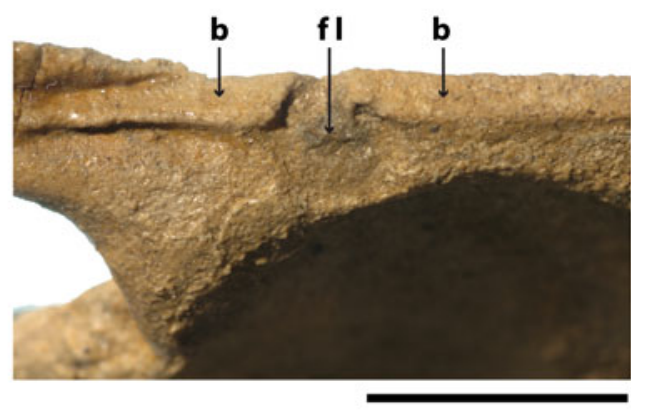

Moreover, selective preservation of the fibrous (calcified) part of the resilium, visible as a thin black patch in the resilifer (Fig. 1d), might indicate the presence of a thick uncalcified median core with lower preservation potential, which is the second important character of this modern ligament type (Waller 1978). Such a selective preservation of the fibrous ligament has also been observed in later pectinids in which the ligament state is unequivocal (e.g., Hautmann 2001, pl. 13, Figs. 2, 6). Narrow bourrelets occasionally occur in gerontic individuals of various pectinid species (Newell 1938, Fig. 13), possibly formed when overall shell growth has ceased while the inner shell layer at which the ligament system is fixed still thickens. An alternative interpretation is that the narrow bourrelets of Pleuronectites were atavistic, indicating derivation from an ancestor with an alivincular-areate ligament system. The latter interpretation seems more likely, because shell size and thickness of the present specimen are only moderate for P. laevigatus.

Because of the uniqueness of the siliceous specimen, no thin sections have been made to examine whether relics of the original shell structure were preserved. However, some basic information on the outer shell layer is available from calcareously preserved specimens. In his pioneering study, Bøggild (1930, p. 268) noted that the shell of "Pecten" laevigatus is "built up of large prisms which lie in the radial direction; every prism reaches from the upper to the under side of the shell and its breadth (in the concentrical direction) is ca. $0.2 \mathrm{~mm}$. The optical axes are orientated normally to the prisms and lie in the concentrical direction." This description most likely refers to the outer shell layer, because the inner shell layer of Pleuronectites laevigatus is usually dissolved (Waller 2005). The only other pteriomorphian bivalve family where radially elongated simple prisms are common is Propeamussiidae Abbot, 1954 (Carter 1990, pp. 256-257; Carter, pers. comm.).

Based on the new observations, earlier diagnoses of Pleuronectites by Newell (1969) and Waller (2005) can be revised as follows:

\section{Systematic palaeontology}

Family Pectinidae Rafinesque-Schmaltz, 1815.

Genus Pleuronectites Schlotheim, 1820.

Type species

Pleuronectites laevigatus Schlotheim, 1820, by subsequent designation (Fischer 1886). 
Revised diagnosis

Comparatively large pectinids with procrescent discs; height of valves greater than length; left valve more convex than right valve; shell exterior smooth or with radial ribs; right anterior auricle with auricular scroll and deep byssal notch; ctenolium present; right posterior auricle obtuse but well delimited, not projecting above hinge margin; auricles of left valve lacking auricular sinuses and dorsally levelling with hinge margin; ligament alivincular-alate, small bourrelets may be present; hinge without resilial- and infraresilial teeth; shell interior without buttresses; shell bimineralic, outer shell layer calcitic, thin, with coarse, radially arranged prism-like structures, inner shell layer aragonitic.

\section{Other species}

More than a dozen species have been assigned to Pleuronectites (Diener 1923, pp. 85-86; Allasinaz 1972, p. 223; Waller 2005, pp. 38-40). Some of these might be synonymous with the type species, as suggested by Waller (2005, p. 39) for Pecten laterestriatus Philippi, 1899 and Pecten schmiederi Giebel, 1856. Other assignments were clearly erroneous (see below) or cannot be verified due to insufficient morphological information. Currently, only the type species can be definitely included in Pleuronectites.

\section{Distribution}

Anisian-Ladinian; Germany, Hungary, Sardinia, Afghanistan, China.

\section{Erroneously assigned species}

Many species that have been assigned to Pleuronectites do not fulfil the revised diagnosis of Pleuronectites. These unjustified generic assignments have had a detrimental influence on phylogenetic reconstructions, because they have led to taxonomical concepts of Pleuronectites that mixed characters of true Pleuronectites and other genera, particularly entoliids. More specifically, one of the specimens assigned to "Pleuronectites" balatonicus (Bittner, 1901) by Allasinaz (1972) has nicely preserved basal auricular and lateral disk buttresses (Allasinaz 1972, pl. 43, Fig. $6 \mathrm{~b}-\mathrm{c}$ ), which are characteristic of entoliids (Waller 2006) but are lacking in Pleuronectites. According to Waller (2005, p. 39), this specimen belongs to Pecten inornatus Stoppani, 1858, which he assigned to the entoliid genus Crenamussium Newton, 1987 [in Newton et al.]. Waller (2005, p. 39) also stated that the morphology of Pleuronectites meeki Newell and Boyd, 1995 suggests an entoliid affinity of this species. However, Waller (2005) was probably similarly misled when he erected "Pleuronectites" newelli Waller, 2005. Typical entoliid characters of this species that are not observed in Pleuronectites include the equilateral disk, the similar convexity of both valves, and a posterior auricle in the left (?) valve that projects distally above the hinge margin. Waller (2005) mentioned the presence of a ctenolium in the right valve, but he did not illustrate this key character. Given the comparatively poor preservation of his material, it appears possible that he was deluded by a fragment of another taxon or by a preservation artefact.

\section{Phylogenetic implications}

Pleuronectites lacks virtually all internal characters that define Entoliidae (cf. Waller 2006): there are no resilial teeth, no basal auricular and lateral disk buttresses, and no outer ligament articulation (Fig. 1b-d). Additionally, Pleuronectites differs from Entoliidae in the inequilateral shell, valves with a differential convexity, and a straight dorsal margin of the posterior auricles in both valves. Moreover, the narrow bourrelets probably indicate a derivation of Pleuronectites from an alivincular-areate ancestor, which would exclude entoliids that had a fully evolved alivincular-alate ligament system already in the late Devonian (Waller 2006).

The observed shell characters of Pleuronectites are not singular in Late Palaeozoic to Early Mesozoic bivalves. Most striking are morphological similarities with Leptochondria Bittner, 1891, a genus that survived the endPermian mass extinction event and persisted until the Norian (Newell and Boyd 1995). Similarities between both genera include (1) slightly procrescent discs, (2) a nearly flat right valve with a deeply incised byssal notch, (3) a vaulted left valve that lacks an anterior auricular sinus, (4) the presence of an anterior auricular scroll in the right valve, and (5) the lack of teeth and internal buttresses (for a detailed description of Leptochondria see, e.g., Newell and Boyd 1995). The only relevant differences between the two genera are the newly evolved pectinoid autapomorphies in Pleuronectites, i.e. the alivincular-alate ligament system and the ctenolium. Based on the agreement in the character pattern and on the stratigraphical distribution of both taxa, it is suggested that Leptochondria or a closely related taxon gave rise to Pleuronectites around the transition from the Early to the Middle Triassic.

Derivation of Pleuronectites from Leptochondria implies that the ctenolium and the alivincular-alate ligament system evolved more or less coevally, possibly as an evolutionary response to a marked size increase: Leptochondria generally does not exceed $2 \mathrm{~cm}$ in height (Newell and Boyd 1995), whereas a height of $10 \mathrm{~cm}$ is not unusual 
for $P$. laevigatus. These large dimensions might have favoured improved byssal attachment by the ctenolium as well as evolutionary changes in the ligament system, which had to adapt to the increased weight of the domed upper valve. The newly evolved alivincular-alate ligament compensated the high weight of the upper valve by the internal position of the resilium, which lengthened the lever arm for opening the valves. The apparent disadvantage of this arrangement, i.e. that the more ventrally located parts of the resilium are relatively less compressed at given angel of valve closure than in a submarginal resilium, has been compensated by the lamellar core that allowed higher overall compression. This effect has been confirmed by experimental studies, which have shown that the percentage compression undergone by the resilium when the valves close is $45 \%$ in Recent Pecten (internal resilium with lamellar core), compared to $30 \%$ in Recent Ostrea (submarginal resilium that is completely fibrous; Trueman 1953). Life habit and functional morphology of Pleuronectites therefore suggest that the primary adaptation of the alivincular-alate ligament in pectinids was not swimming, as previously supposed (Trueman 1953, p. 465; Waller 2006 , p. 335), but improvement of valve opening in a sessile species with a heavy upper valve.

Leptochondria has traditionally been placed within Aviculopectinidae Meek and Hayden, 1864 (Newell 1969). An alternative view was later advocated by Newell and Boyd (1995), who removed Leptochondria from Aviculopectinidae on grounds of the lack of an anterior auricular sinus in the left valve. Based on this character, they suggested a link with Pseudomonotidae Newell, 1938, but it is unlikely that Leptochondria evolved from such a highly specialized group with a very peculiar shell morphology. Leptochondria rather appears to be a derived aviculopectinoid, in which the left anterior auricular sinus has been closed in order to protect the byssus extrusion in the opposite valve. The proposed link between Leptochondria and Pleuronectites therefore corroborates an earlier hypothesis of Newell (1938) that Pectinidae descended from Aviculopectinidae (Aviculopectinoidea of most recent authors).

An alternative hypothesis tentatively proposed by $\mathrm{Ne}$ well and Boyd (1985) is that Pectinidae and aviculopectinoids were linked by the Permian streblochondriid genus Guizhoupecten Chen, 1962, which externally resembles "Chlamys-group" (Hertlein 1969) pectinids but has a primitive ligament system and lacks a ctenolium. Because Pleuronectites derived from a morphologically quite different lineage of the Aviculopectinoidea, the Newell and Boyd (1985) hypothesis raises the question whether Pectinidae were mono- or diphylitic. Parallel evolution could likewise explain (i) external similarities of Guizhoupecten and the "Chlamys-group" (i.e. "Chlamys-group" pectinids evolved from Pleuronectites: monophyletic case) or (ii) dual invention of ctenolium plus alivincular-alate ligament system in Pleuronectites and the "Chlamys-group" (i.e. "Chlamys-group" pectinids evolved from Guizhoupecten: diphyletic case). Although the first option is more parsimonious, a definite test requires a detailed knowledge on the internal morphology of Middle Triassic Chlamys-like pectinoids, which is not yet available.

Acknowledgments Günter Schweigert, Stuttgart, kindly made specimen SMNS 18926 available for this study. I thank Christian Klug and two anonymous reviewers for helpful remarks on the manuscript.

\section{References}

Abbot, R.T. 1954. American seashells. New York: Van Nostrand.

Allasinaz, A. 1972. Revisione dei Pettinidi Triassici. Rivista Italiana di Paleontologia e Stratigrafia 78: 189-428.

Bittner, A. 1891. Triaspetrefakten von Balia in Kleinasien. Jahrbuch der k. k. Geologischen Reichsanstalt 41: 97-116.

Bittner, A. 1901. Lamellibranchiaten aus der Trias des Bakonyer Waldes. Resultate der wissenschaftlichen Erforschung des Balatonsees, Anhang: Palaeontologie der Umgebung des Balatonsees II. Band 3: 1-106.

Bøggild, O.B. 1930. The shell structure of the Mollusks. Det Kongelige Danske Videnskabernes Selskabs Skrifter. Naturvidenskabelig og Mathematisk Afdeling, ser. 9(2): 231-326.

Carter, J.G. 1990. Evolutionary significance of the shell microstructure in the Palaeotaxodonta, Pteriomorphia and Isofilibranchia (Bivalvia, Mollusca). In Skeletal biomineralisation: patterns, processes and evolutionary trends, vol. I, ed. J.G. Carter, 135296. New York: Van Nostrand Reinhold.

Chen, Chu-Chen. 1962. Lamellibranchiata from the Upper Permian of Ziyun, Guizhou (Kueichow). Acta Palaeontologica Sinica 10: 199-205.

Deutsche Stratigraphische Kommission (ed.) (2002). Stratigraphische Tabelle von Deutschland 2002. Potsdam: GFZ.

Diener, C. 1923. Lamellibranchiata triadica. In Fossilium catalogus I: Animalia. Pars 19, ed. C. Diener, 1-257. Berlin: W. Junk.

Fischer, P.H. 1880-1887. Manuel de conchyliologie et de paléontologie conchyliologique. Paris: F. Savy.

Giebel, C. 1856. Die Versteinerungen im Muschelkalk von Lieskau bei Halle. Abhandlungen des naturwissenschaftlichen Vereins für die Provinz Sachsen und Thüringen 1: 52-126.

Hagdorn, H. 1995. Farbmuster und Pseudoskulptur bei Muschelkalkfossilien. Neues Jahrbuch für Geologie und Paläontologie, Abhandlungen 195: 85-108.

Hautmann, M. 2001. Die Muschelfauna der Nayband-Formation (Obertrias, Nor-Rhät) des östlichen Zentraliran. Beringeria 29: $1-181$.

Hautmann, M. 2004. Early Mesozoic evolution of alivincular bivalve ligaments and its implications for the timing of the „Mesozoic marine revolution". Lethaia 37: 165-172.

Hertlein, L.G. 1969. Family Pectinidae Rafinesque, 1815. In Treatise on Invertebrate Paleontology, Part N, Mollusca 6, vol. 1, ed. R.C. Moore, N348-N373. Boulder: Geological Society of America and University of Kansas Press.

Korobkov, I.A. 1960. Anisomyaria. In Osnovy Paleontologii, vol. 3, ed. A. G. Eberzin, 83. Moscow: Academy Nauk USSR.

Meek, F.B., and F.V. Hayden. 1864. Palaeontology of the Upper Missouri. Smithsonian Contributions to Knowledge 14: 1-135. 
Newell, N.D. 1938. Late Paleozoic Pelecypods: Pectinacea. State Geological Survey of Kansas 10: 1-123. (for 1937).

Newell, N.D. 1969. Family Aviculopectinidae. In Treatise on invertebrate paleontology, Part N, Mollusca 6, vol. 1, ed. R.C. Moore, N335-N341. Boulder: Geological Society of America and University of Kansas Press.

Newell, N.D., and D.W. Boyd. 1985. Permian Scallops of the Pectinacean Family Streblochondriidae. American Museum Novitates 2831: 1-13.

Newell, N.D., and D.W. Boyd. 1995. Pectinoid bivalves of the Permian-Triassic crisis. Bulletin of the American Museum of Natural History 227: 1-95.

Newton, C.R., M.T. Whalen, J.B. Thompson, N. Prins, and D. Delalla. 1987. Systematics and paleoecology of Norian (late Triassic) Bivalves from a tropical island arc: Wallowa terrane, Oregon. Journal of Paleontology 61, Supplement to No. 4., Memoir 22: 1-83.

Philippi, E. 1899. Über zwei neue Zweischaler-Arten von paläozoischem Habitus aus deutschem Muschelkalk. Zeitschrift der Deutschen Geologischen Gesellschaft 51: 62-67.

Rafinesque-Schmaltz, C.S. 1815. Analyse de la nature ou tableau de $l^{\prime}$ Univers $d t$ des corps organisés. Palermo: Jean Barravecchia.

Schmidt, M. 1928. Die Lebewelt unser Trias. Öhringen: Hohenlohesche Buchhandlung F. Rau.

Schmidt, M. 1938. Die Lebewelt unserer Trias. Nachtrag. Öhringen: Hohenlohesche Buchhandlung F. Rau.

Stoppani, A. 1858-1860. Paléontologie Lombarde ou description des fossiles de Lombardie. I. Les Pétrifications $d^{\prime}$ Esino ou description des fossiles appartenants au dépot triasique supérieur des environs d'Esio en Lombardia. Milan: Joseph Bernardoni.

Trueman, E.R. 1953. Observations on certain mechanical properties of the ligament of Pecten. Journal of Experimental Biology 30: 453-467.

von Schlotheim, E.F. 1820. Die Petrefactenkunde auf ihrem jetzigen Standpunkte durch die Beschreibung seiner Sammlung versteinerter und fossiler Überreste des Thier- und Pflanzenreichs der Vorwelt erläutert. Gotha: Becker'sche Buchhandlung.

von Schlotheim, E.F. 1823. Nachträge zur Petrefactenkunde. Gotha: Becker'sche Buchhandlung.

Waller, T.R. 1978. Morphology, morphoclines and a new classification of the Pteriomorphia (Mollusca: Bivalvia). Philosophical Transactions of the Royal Society of London, Ser. B 284: 345365.

Waller, T.R. 1984. The ctenolium of scallop shells: functional morphology and evolution of a key family-level character in the Pectinacea (Mollusca: Bivalvia). Malacologia 25: 203-219.

Waller, T.R. 2005. Systematic paleontology. In Middle Triassic Pteriomorphian Bivalvia (Mollusca) from the New Pass Range, west-central Nevada: Systematics, biostratigraphy, paleoecology, and paleobiogeography, ed. T. R. Waller and G. D. Stanley, 7-50. Journal of Paleontology, Memoir 61.

Waller, T.R. 2006. Phylogeny of families in the Pectinoidea (Mollusca: Bivalvia): Importance of the fossil record. Zoological Journal of the Linnean Society 148: 313-342. 